\title{
In situ environmental transmission electron microscopy investigation of core-shell supported co-catalyst system for optimized visible-light water splitting
}

Cavalca, Filippo; Laursen, Anders Bo; Dionigi, Fabio; Dahl, Søren; Wagner, Jakob Birkedal; Hansen, Thomas Willum

Publication date:

2012

Link back to DTU Orbit

Citation (APA):

Cavalca, F., Laursen, A. B., Dionigi, F., Dahl, S., Wagner, J. B., \& Hansen, T. W. (2012). In situ environmental transmission electron microscopy investigation of core-shell supported co-catalyst system for optimized visiblelight water splitting. Abstract from 15th European Microscopy Congress 2012, Manchester, United Kingdom.

\section{General rights}

Copyright and moral rights for the publications made accessible in the public portal are retained by the authors and/or other copyright owners and it is a condition of accessing publications that users recognise and abide by the legal requirements associated with these rights.

- Users may download and print one copy of any publication from the public portal for the purpose of private study or research.

- You may not further distribute the material or use it for any profit-making activity or commercial gain

- You may freely distribute the URL identifying the publication in the public portal 


\title{
In situ environmental transmission electron microscopy investigation of core-shell supported co-catalyst system for optimized visible-light water splitting
}

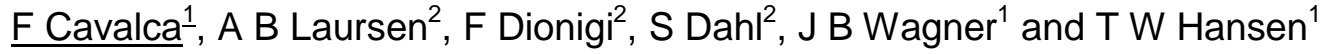 \\ 1. Center for Electron Nanoscopy, Technical University of Denmark, DK-2800 Kgs. Lyngby, Denmark \\ 2. Center for Individual Nanoparticle Functionality, Technical University of Denmark, DK-2800 Kgs. Lyngby, \\ Denmark
}

filippo.cavalca@cen.dtu.dk

Keywords: TEM, photocatalysis, core-shell

As a result of diminishing fossil fuel reserves, there is an increasing need to switch energy dependence to renewable resources such as sunlight. Photocatalysts provide a viable route for converting solar energy into chemical bonds. In order to optimize the performance of such materials, a fundamental understanding of their reaction mechanisms, chemical behavior, structure and morphology before, during and after reaction using in situ investigations is necessary. Here, we focus on the in situ characterization of photocatalysts [1] in an environmental transmission electron microscope (ETEM) [2,3]. Such fundamental insight can be used for further material optimization with respect to performance and stability [4].

The activity of photocatalysts for water splitting under visible light exposure can be enhanced by adding co-catalysts for the hydrogen evolution reaction (HER) on their surface, Pt being one of the most commonly used. Pt is a reversible catalyst for HER, meaning that unless precautions are taken it will also efficiently catalyze the reverse reaction, resulting in a loss of net activity. The addition of a shell on top of the co-catalyst has proven an efficient method to dramatically reduce the reverse reaction in both catalytic [5] and photocatalytic systems [6]. Encapsulated Pt is obtained by substrate reduction in $\mathrm{H} 2$ and is a novel promising system for enhanced water splitting using visible light.

In this work the encapsulation of supported co-catalysts on a number of semiconductor substrates including SrTiO3 and TiO2 is studied using ETEM techniques (Fig.1). The shell formation mechanism is studied in situ as a function of reaction conditions such as temperature, pressure, time, and atmosphere composition. Catalytic efficiency of the encapsulated samples is tested in parallel using micro-reactors [7] allowing for direct correlation of reaction conditions and catalyst performance. 


\section{References}

[1] J M Herrmann, Topics in Catalysis 34 (2005), p. 49-65.

[2] T W Hansen, J B Wagner, R E Dunin-Borkowski, Materials Science and Technology 26 (2010), p. 1338-1344.

[3] E D Boyes, P L Gai, Ultramicroscopy 67 (1997), p. 219-232.

[4] M Tsujimoto, S Moriguchi, S Isoda, et al. Journal of Electron Microscopy 48 (1999), p. 361-366.

[5] J J Liu, ChemCatChem 3 (2011), p. 934-948.

[6] K Maeda, N Sakamoto, T Ikeda, et al. Chemistry 16 (2010), p. 7750-9.

[7] F Dionigi, P C K Vesborg, T Pedersen, et al., Energy Environ. Sci. 4 (2011), p. 2937-2942

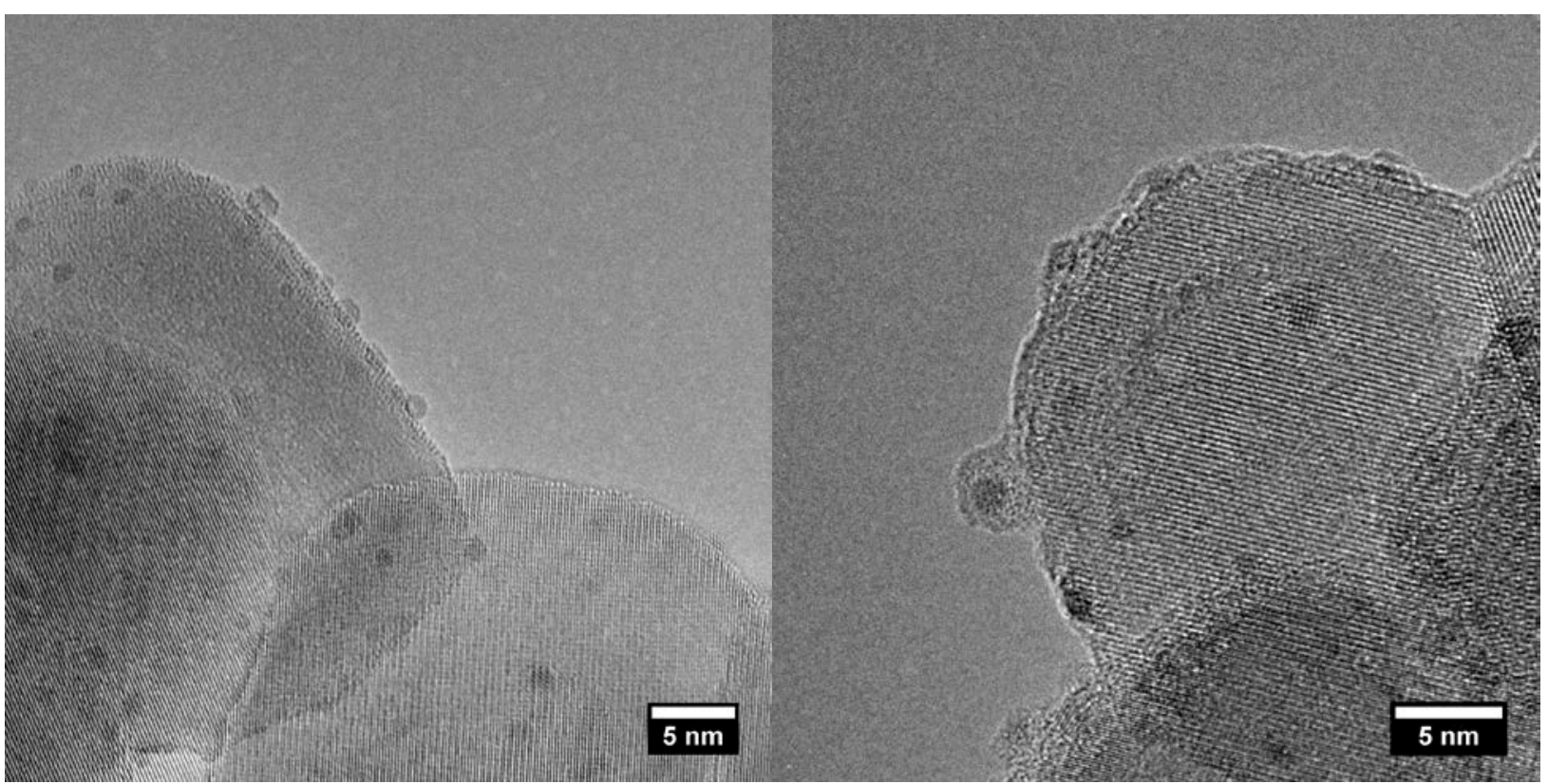

Figure 1. Bright field TEM images of STO-supported Pt nanoparticles before (left) and after (right) hightemperature in situ reduction in $\mathrm{H}_{2}$. 